\title{
Does Educational Disaster Mitigation Need To Be Introduced In School?
}

\author{
Wanjat Kastolani; Revi Mainaki \\ Master Program of Geography Education, Post Graduate School of Universitas Pendidikan Indonesia, \\ Bandung
}

\begin{abstract}
Indonesia is an archipelagic country in subduction of three global plates namely Eurasia, Pacific and Indo-Australia. Make it has many active volcanoes and mountain morphology that are prone to earthquakes, tsunamis and landslides. In astronomical location Indonesia is a country in tropical latitude with high rainfall and irradiation. Makes it vulnerable to atmospheric and hydrosphere disasters such as drought, tropical storms and floods. Also has multicultural population that makes it vulnerable to social conflict. Various factors indicate that Indonesia is a country prone to various disasters. Need disaster mitigation socialization efforts early on. This study describe the need to introduce disaster mitigation education as one of the efforts of disaster risk reduction in schools to students. This study uses literature study method by collecting various written references from books and publications of research results. Use descriftive analysis tecnique for process data. The results show that disaster mitigation education needs to be introduced at the level of schooling in Indonesia. As one of the efforts to prepare the people of Indonesia disaster preparedness. Disaster mitigation education should be included in the curriculum of education, especially on subjects that have a correlation therein.
\end{abstract}

Key Word: Disaster Mitigation, Educational, Schools

\section{Introduction}

Indonesia is an archipelagic country that has about 13,500 islands. Is a country that is in tropical latitude climate that makes it vulnerable or at risk of disasters caused by the dynamics of the atmosphere of tropical storms. Being in a subduction zone or encounter between the Eurasian and Pacific Plate making it prone to earthquakes and has many volcanoes due to the formation of two mountainous paths of the world that is the Pacific Circum and Sirkum Mediteranian with morphology of the hills, this makes it at risk of landslides and volcanic eruptions.

In addition, tectonic activity that occurs in the subduction zone located on the seabed make some areas in Indonesia prone to the tsunami. The large number of islands in Indonesia with the geographic conditions of each diverse island also makes the diversity of tribes and languages as well as cultures and religions, it also becomes a potential social 
catastrophe. ${ }^{[1]}$ Quarantelli (1998) in Lestari (2006) describes disaster as an actual occurrence, more than one potential or more threat is termed as more than an actual threat or termed as the realization of danger.

${ }^{[2]}$ Suryanti (2010) The disaster occurring in an area will have a direct impact on the surrounding community, the impact is a perceived implication that increases awareness and preparedness in the face of disaster need to be improved to make the community around ready and alert with possible disasters happen. ${ }^{[3]}$ M. Zein (2010) the high level of disaster occurrence in Indonesia, both natural and non-natural disasters in Indonesia that have an immediate impact on the community make people have experience about it and it becomes a capital in socialization efforts related to disaster mitigation

Based on data from ESCAP ${ }^{[4]}$ detailing the Asia-Pacific region of a world-wide economic and social survey body detailing some of the disastrous countries of 1980-2009 Indonesia ranks second in the number of deaths due to natural disasters in the Asia-Pacific region. Statistically the loss of natural disasters has also resulted in a loss of 22.5 billion US Dollars. However, Indonesia is a country with high levels of vulnerability and vulnerability to disasters, so the risk of disaster can not be avoided, but by building disaster preparedness in Indonesian society is expected to reduce the risk of disaster itself.

Each region has different vulnerabilities and types of disasters that need different understanding and handling of disaster preparedness. This is what should be built on the people of Indonesia, aware of the potential and vulnerability of disasters that will occur in the environment around his place of life. So that makes the community more prepared and alert in the face of disaster that will happen, the term is known as disaster mitigation.

The question is how to grow and provide an overview to the community regarding disaster mitigation. One of the areas relevant to it is the field of education. Education based on the law number 20 year 2003 article 1 is an effort to realize the learning atmosphere and the learning process so that active learners can develop the potential in the form of positive values needed for themselves, society, nation and state.

Positive values of awareness of the vulnerability of the surrounding environment are vulnerable and are at risk of disaster. With regard to education, we can not escape from school as an educational institution for the community. Education and growth of public awareness to understand disaster mitigation efforts are closely related to each other. Through schools we can include learning materials regarding disaster mitigation as a form of growing awareness with values inside. But how important is the introduction of disaster mitigation to be done in education? For what is described then the title in this article "Does educational disaster mitigation need to be introduced in school?"

Based on what has been described in the previous background, the problem formulation in this study is "Should disaster mitigation education be introduced in Indonesian schools?" with The purpose of this study is to explain how important disaster mitigation education is introduced in the existing school environment in Indonesia. Value of this research is Theoretically, it can enrich referenasi regarding disaster mitigation education and it is practically expected to be an input for the related institution to determine the policy concerning disaster mitigation education.

\section{Methods}

This research uses qualitative approach The method used in this study is a literature study that examines a problem that is associated with various relevant theories contained in scientific references in the form of journals, books, print and electronic media then data would analisys with descriftive method. 


\section{Results}

Earth surface hydrosphere layer or commonly known by the term disaster caused by a layer of water on the surface of the earth has its own hazards and vulnerabilities. The dangers of the water itself arise when the volume or amount of water exceeds the capacity, the flow of water so swift that it can attract living creatures into the stream, debris carried by water can injure or damage what passes through, various infrastructure can be damaged by mud Oil and other pollutants carried by the water itself.

Disaster parameters caused by the dynamics of this hydrosphere are the extent in the form of depth, water volume, sediment flow rate, duration of puddle and dasyatnya wave for disaster like tsunami. The disaster caused by hydraulic dynamics is certainly caused by the high rainfall in a place on the surface of the earth, the movement of tectonic plates that cause a tsunami.

This needs to be of particular concern to the community especially those living in vulnerable locations with disasters caused by the dynamics of the hydrosphere itself. Knowledge of this will make people aware of the risk of disasters, the main mitigation that can be done include ${ }^{[5-6]}$ (a) Perform physical construction to with stand the volume and swift flow of water. Preparation of retaining embankments, reforestation of water catchment areas and improvement of drainage system in urban areas; (b) Establish an early warning system such as utilizing the advancement of science and technology that has begun to develop when the capacity of the catchment area exceeds the limits or currents that are around too strong then the system can attract people to immediately move away or perform an action; (c) Increase community participation in disaster mitigation efforts. Conducting development in accordance with the place for example not too close to the shore to reduce the impact in the event of a tsunami.

Disasters due to the dynamics of lithosphere or dynamics of the movement of the earth's shell are included as a result of land movements including earthquakes, landslides and volcanic eruptions. The awesomeness parameters of this disaster for earthquakes of a certain scale (Richter, Mercalli and so on), for landslides are volumes of land undergoing movement and for volcanic eruptions include volumes and types of material removed from the volcano itself. Disaster risk reduction efforts caused by the dynamics of lithosphere such as earthquakes are to build houses with earthquake resistant construction and earthquake warning system, for landslide disaster can be done by vegetative and technical effort, while for disaster volcanic eruption should stay away from center of eruption or caldera and also know sign Will happen volcanic eruptions.

Major disaster mitigation measures that can be undertaken with regard to this type of disaster include ${ }^{[7]}$ (a) evelopment of a qualified infrastructure is certainly earthquake resistant, buildings that resist several types of materials released by volcanoes and avoid areas that are very vulnerable to disasters due to the dynamics of lithosphere; (b) Increasing public awareness recognizes the signs and symptoms of the occurrence of disasters caused by the dynamics of the lithosphere; (c) Community participation that is aware of the hazards and symptoms of this type of disaster.

Disasters caused by atmospheric dynamics include drought, typhoon, hiricane, whirlwind, fohn wind, tornadoes and tropical storms. This is because the air pressure and the suction of wind pressure within a certain time will cause losses, the main cause of this type of disaster is the difference between one place to another. The magnitude level parameters of this type of disaster are the time pages and the higher the scale. This type of disaster can come suddenly so the hall required is the use of technology to provide early warning of the occurrence of this disaster.

Some of the buildings in this area and very vulnerable to the heat should provide a basement for evacuation or emergency of this type of disaster. The main mitigation efforts 
of these disasters are early warning and physical infrastructure development that is resistant to this type of disaster. Especially for drought humans must realize the importance of the existence of water for their lives.

Technological failures usually begin with explosions that cause death, damage to building infrastructure, releases harmful sanitary substances, accidents cause injury to the victim. The awesomeness parameters of this disaster are the quantity of debt generated, the temperature of the event, the extent of the affected area. Potential to reduce hazards by raising security standards of technology and human consciousness to be more careful in using technology. This type of disaster belongs to a disaster that is unpredictable because it just happens, humans must be fully aware of the risks and dangers of this disaster in order to avoid it.

\section{Discussion}

${ }^{[8]}$ Annisa (2011) explains that disaster is anything that happens both due to nature and human impact itself that has the potential to interfere with life, harm human beings, cause natural damage either caused by natural, non-natural or human factors. Another notion of disaster is an event that can threaten the life or human livelihood caused by certain factors.

From this understanding it can be seen that the concept of phenomena is said to be a disaster when there are humans who are harmed, when there is a flood or tsunami in a place that is on the surface of the earth but no harm to humans then it can be ascertained if it is not a disaster. While the term mitigation is an action to reduce the impact of the occurrence of a disaster done either before, during and after the disaster.

Mitigation can also be a human readiness of the occurrence of a disaster event, so that when the disaster occurs man is no longer surprised to lose the things he has, including the loss of his family or loved ones. The following are some of the most vulnerable disasters occurring in Indonesia and the mitigation of disaster mitigation and the causes of such disasters include the following ${ }^{[10]}$ atmosphere, hydrosphere, antroposphere and failed technology.

Based on what has been described previously, disaster mitigation has an urgency to be introduced in education, especially in the school environment in Indonesia, some of the reasons that underlie it are ${ }^{[9-13]}$ (a) each region in Indonesia has certain characteristics and these characteristics also indicate the different vulnerabilities of disaster that occur knowledge of disaster mitigation built through education at least can raise awareness of the disaster mitigation of the population; (b) Indonesia as a country that is very vulnerable to various natural disasters that occur is appropriate to include the value of disaster mitigation in education especially in the environment school; (c) Any disaster mitigation effort required participation and awareness of the population itself means that without the knowledge and awareness of mitigation efforts only a concept; (d) education is an effort to instill positive values, so that through knowledge education and awareness of disaster mitigation is expected to be implanted to the community; (e) Through disaster mitigation education the population at least knows what should be done both before, during and after a disaster; (f) Disaster mitigation education launched early will make people more prepared and alert in the face of disaster, that is ready with all lost property and loss of the nearest person or family.

Those are some of the reasons why the importance of disaster mitigation education is applied in schools with a certain intensity. Disaster mitigation should be included in curriculum units in schools in accordance with potential disasters that can occur, as done in some developed countries and of course also use an approach appropriate to the conditions of child development and growth ${ }^{[14-16]}$. But to be able to enter school, there must be a centralized policy and we can get some developed countries like disaster mitigation 
management in Canada, the results of ${ }^{[17]}$ Henstra and Gordonmcbean (2005) research show the measurement of how disaster mitigation policy in the country. The need for measurement before determining the disaster mitigation policy is included in the rules in Indonesia, especially in schools such as the results of ${ }^{[18]}$ Adefisoye (2015) research that conducts an assessment of the disaster mitigation policy that has been done, this will be the first input inputs of how disaster mitigation should be included in government policy and there is a special budget of disaster mitigation result of research of ${ }^{[19]}$ Phaup (2010) et al shows how important budget in disaster mitigation. If clever to see this situation that potential and disaster vulnerability can be a separate business opportunity such as the results of research ${ }^{[20]}$ Dufty et al (2014) that the vulnerability or potential disaster can be a business opportunity, especially in community skills training and procurement various disaster preparedness equipment.

\section{Congclusions}

Based on what Indonesia has previously described as a country that has a high degree of vulnerability to disasters, whether disaster caused by the dynamics of lithosphere, hydrosphere, atmosphere and technological failure, the need for awareness of the people of Indonesia with regard to disaster mitigation. Growth of this awareness can be done through education and talk about education is not separated from the school as a formal educational institution in Indonesia. The reason why the growth of disaster mitigation efforts is done in the field of education is because Indonesia is a disaster-prone country, education inculcates positive values that can of course be inserted the values of disaster mitigation.

The results of previous exposure show how urgency of disaster mitigation education is important to be introduced in Indonesia. So it should be designed a curriculum in which insert disaster mitigation values in other words the values are included in some or even all subjects in an integrated manner.

Acknowledgments are especially for Allah SWT because thanks to his grace this paper can be solved as it should be, also to Rasulullah SAW who has brought us into a period of civilization. Acknowledgments to all parties who assisted the research include lecturers and staff in the Geography Education Departement, Social Science Education Departement and Geography Education Program, School of Postgraduate, Universitas Pendidikan Indonesia and all parties who can not Mentioned one by one.

\section{Reference}

1. F.F. Lestari. Penerapan Sistem Informasi Geografis Dalam Pemetaan Daerah Rawan Longsor di Kabupaten Bogor. (Bogor: Institut Pertanian Bogor, 2008).

2. Suryanti et al. Motivasi dan Partisipasi Masyarakat dalam Upaya Pengurangan Multirisiko Bencana di Kawasan Kepesisiran Parangtritis dalam Penaksiran Multirisiko Bencana di Wilayah Kepesisiran Parangtritis, Yogyakarta. (Yogyakarta: PSBA Universitas Gadjah Mada, 2010)

3. M. Zein. Community Based Approach to Flood Hazard and Vulnerability Assessment in Flood Prone Area: A Case Study in Kelurahan Sewu, Surakarta City, Indonesia. (Thesis, ITC, The Netherland, 2010)

4. M. C. Ulum. Governance dan Capacity Building Dalam Manajemen Bencana Banjir Di Indonesia. Jurnal Penanggulangan Bencana, 4, 2, 5-12, (2013). 
5. W. Adiyoso, H. Kanegae. The Effect Of Different Disaster Education Programs On Tsunami Preparedness Among Schoolchildren In Aceh, Indonesia. Disaster Mitigation of Cultural Heritage and Historic Cities Journal. 6, 165-172 (July 2012).

6. J. O. B. Rotimi, S. Wilkinson. Improving environmental management legislation to facilitate postdisaster reconstruction. International Journal of Disaster Resilience in the Built Environment, 5, 1, (2014).

7. M. Moore, H.R. Trujillo, B. K. Stearns, R. B. Davila, D. K. Evans. Learning from Exemplary Practices in International Disaster Management: A Fresh Avenue to Inform U.S. Policy?. Journal of Homeland Security and Emergency Management, 6, 1, (2009).

8. Annisa. Zonasi risiko bencana banjir akibat sea level rise. (Surabaya: ITS, 2011)

9. A.W Conburn, RJS Spent, A. Pomonis. Mitigasi Bencana, Program Pelatihan Manajemen Bencana. Second Edition. (Cambrige Architectural Research Limited, 1994)

10. M. Tanudidjaja. Bumi dan Antariksa. (Jakarta : Depdikbud, 1995)

11. P. Putra. Penataan Ruang Berbasis Mitigasi Bencana Di Kabupaten Kepulauan Mentawai. Jurnal Penanggulangan Bencana. 2, 1, 11-20 (2011)

12. A.W Conburn, RJS Spent, A. Pomonis. Mitigasi Bencana, Program Pelatihan Manajemen Bencana. Second Edition. (Cambrige Architectural Research Limited, 1994)

13. L. Gibbs, M.D. Pietro, A. Harris, G. Ireton, S. Mordech, M. Roberts, J. Sinclair, R. Wraith. Core Principles For A Community-Based Approach To Supporting Child Disaster Recovery. Australian Journal of Emergency Management I. 29, 1, 17-24, (2014).

14. B. R. Guerdan. Disaster Preparedness and Disaster Management: The Development and Piloting of a Self-Assessment Survey to Judge the Adequacy of Community-Based Physician Knowledge American Journal of 32 Clinical Medicine. 6, 3, (2009).

15. H. Boon, L. Brown, P. Pagliano. Emergency planning for students with disabilities: a survey of Australian schools. Australian Journal of Emergency Management I. 29, 1, 45-49, (2014).

16. T.Nadu, I. Asharose, I.Saizen, P. Kumar, C. Sasi. Awareness Workshop as an Effective Tool and Approach for Education in Disaster Risk Reduction: A Case Study from Sustainability. Sustainability Journal. 7, 8965-8984, (2015).

17. D. Henstra, Gordonmcbean. Canadian Disaster Management Policy: Moving toward a Paradigm Shift?. Canadian Public Policy/ / Analyse de Politiques Journal. 31, 3, 303$318,(2005)$.

18. T. Adefisoye. An Assessment Of Nigeria's Institutional Capacity In Disaster Management. Scientific Research Journal (SCIRJ), 3, 1, (2015).

19. M. Phaup and C.Kirschner Focusing on the Good Times.. OECD Journal on Budgeting. 1, 1-22, (2010)

20. R.A. Quero, D.L. Salle. Framework for Building Skills in Disaster Risk Management for Businesses Journal of Global Business, 1, 1, (2012). 